\title{
Determining terminal concession durations in seaports: theoretical considerations, applicable techniques and current practices
}

\author{
Christophe Theys* and Theo Notteboom**
}

\begin{abstract}
The awarding of terminals to private operators is considered a prime task of landlord port authorities. Yet, terminal concessions in seaports have only recently gained interest in academic circles. The awarding process poses a complex set of managerial challenges to port authorities, one of the key issues being the determination of the duration of the concession.

Despite the importance of the duration of terminal concessions in seaports, the issue has not received much attention in academic circles. Factors impacting on the duration of contracts, leases or concessions have, however, been studied extensively in other research areas, such as agriculture, coal contracts, franchising and natural gas. This paper uses insights from these academic studies to obtain a better understanding of the impact of concession duration on the stakeholders involved and relates them to empirical evidence on concession length in European seaports. The paper then proposes a classification scheme for the exogenous determination of concession duration, based on techniques developed for Public-Private-Partnerships in large infrastructure projects. In the last section the paper discusses the importance of concession durations to various stakeholders in seaports and illustrates these principles using a case study.
\end{abstract}

Keywords: concessions, seaports, duration, governance.

Submission Date: 14/01/2010 Revision Date: 17/03/2010

Acceptance Date: 17/03/2010

* Corresponding Author, ITMMA - University of Antwerp, Keizerstraat 64, 2000 Antwerp, Belgium, E-mail : crhistophe.theys@ua.ac.be

** ITMMA - University of Antwerp, Keizerstraat 64, 2000 Antwerp, Belgium, Antwerp Maritime Academy, Noordkasteel Oost 6, 2030 Antwerp, Belgium 


\section{Introduction}

Perhaps one of the most fundamental tasks of port authorities under the landlord port model is the awarding of (the use of) terminals to operating companies. However, the management of terminal concessions and leases in seaports is complex, and was already considered so a decade ago (Drewry, 1998). Landlord port authorities are still recurrently faced with important questions related to the procedures in view of selecting the most appropriate operators for their scarce land and the conditions under which these private companies can be given the right to operate the facilities. Awarding bodies thereby often encounter considerable difficulties in various phases of the concession process (see Theys et al., 2010, for examples).

Notwithstanding the importance of a thorough study of the relevant aspects of terminal concessions in seaports, the topic has only recently started attracting academic interest and, as a result, the number of scientific papers dealing with concession issues in seaports is still fairly small and recent. In one of the earlier works on the topic Notteboom (2007) situates seaport concessions within the broader literature on Public-Private-Partnerships (PPP) and stresses their function as port governance tools. Theys et al. (2010) present an extensive overview of different types of terminal awarding procedures and propose an elaborate research agenda for the academia. Pallis et al. (2008) illustrate how terminal concessions might lead to the creation of entry barriers, while Juan et al. (2004) discuss a quantitative methodology for designing concession agreements for the port of Valencia involving regular concession fees and a one-off lump-sum goodwill payment. Engel et al. (2004) suggest awarding terminal concessions on the basis of a Demsetz-alike auction (see Demsetz, 1968) with an upfront payment and a floor-set cargo handling fee, applied to the Chilean ports of Valparaíso and San Antonio. Ferrari and Basta (2009) propose a DEA approach to calculate concession fees for Italian ports.

Our paper focuses on yet another dimension of the awarding process, namely the durations of terminal concessions in seaports, for which we have not found prior scientific research. The paper aims to provide a theoretical and empirical analysis of terminal concession length. First, we analyze which factors impact the duration of terminal concessions or, in other words, which parameters lead to longer respectively shorter durations. In doing so, we will link economic theory on contract durations in other sectors to empirical evidence on concession length in European ports. Next, in Section 3, we consider which techniques are available to determine concession durations and provide a classification scheme. Section 4 then presents a discussion of the importance of concession durations to port authorities and their private partners, after which Section 5 summarizes our main findings. 


\section{Contract length and its determining factors}

\subsection{Background}

In 2004, the European Sea Ports Organisation (ESPO) held an internal survey on the duration of concessions in European (landlord) ports. While the survey generated a fragmented picture on the issue, it revealed a big variety in terminal contract durations in European ports. This fact is confirmed in another recent survey for ESPO (Notteboom, 2008). That survey focused on terminal awarding practices for 43 recent terminal projects in European seaports. The terminal projects related to ports using some form of landlord port management system. Nearly $44 \%$ of the terminals considered started operations recently. For about a quarter of the projects, the awarding and contracting procedures were already completed at the time of the survey, but the terminal had not started up operations yet. In $13 \%$ of the cases the awarding procedure was completed, but the contract with the future operator was not finalized yet. For the remaining cases the awarding procedure had not been started up yet or the awarding procedure was ongoing. Large, medium-sized as well as small terminal projects were represented in the survey. All port ranges in Europe were well represented, except for UK ports where the landlord system is not common. About $61 \%$ of all responses related to container terminal projects (Notteboom, 2008).

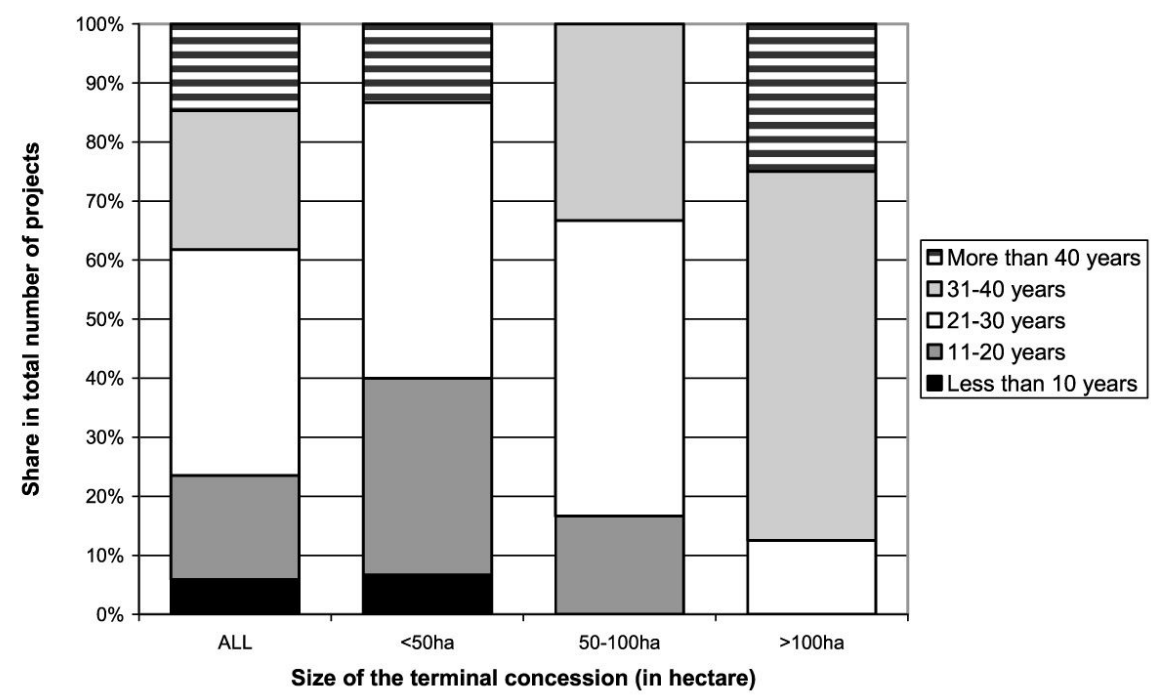

Figure 1. Survey results on the duration of the terminal award 
Contract durations in the survey sample ranged from 4 to 65 years, with two thirds of all terminal contract durations between 21 and 40 years (Figure 1). The study also revealed that $56 \%$ of the terminal award procedures considered existing laws impose minimum and/or maximum limits on the duration of the terminal award contract. In many parts of the world, legislators have developed rough guidelines on concession durations in view of safeguarding free and fair competition in the port sector. For instance, in its failed proposal for a Directive on Market Access to Port Services, the European Commission proposed a series of limited and renewable periods of time for authorizations for providers of port services (European Commission, 2004). An 'authorization' is defined as any permission, including a contract, allowing a natural or legal person to provide one or more categories of port services. A concession agreement is a form of authorization. Article 12 of the Commission's proposal set maximum durations for authorizations depending on the type of investments made. In case the authorization relates to investments by the concessionaire in immovable assets and comparable movable capital assets (such as gantry cranes) the maximum period proposed was 30 years, irrespective of whether or not their ownership will revert to the port authority after the concession period. The European Commission suggested maximum concessions durations of 8 years when there are no investments and 12 years in case of significant investments in movable assets. The (twice proposed but rejected) proposal for an EU directive on market access in European ports did not become legislation, but the discussion held at the time confirms that also legislators are seeking to define some rules on how ports can deal with the issue of the duration of a concession agreement.

Despite this interest, port economic literature has not previously discussed contract lengths of terminal concessions. However, in other sectors such as agriculture, coal mining, franchising and natural gas, empirical observations from studies on factors impacting on the duration of contracts, leases or concessions have resulted in economic theories on the topic. Although it might prove difficult to conduct similar (statistical) studies in the port sector due to limited data availability, some of the duration-related insights are also valuable to terminal concessions.

\subsection{Contract duration in economic literature}

In a seminal work on durations of agricultural land leases ${ }^{1}$ Cheung (1969) points to the importance of longer lease durations when the value of assets in which the tenant invests is hard to evaluate (e.g. as a result of uncertainties in depreciation) or when transaction costs to transfer assets to the landlord are high. When the landlord invests in site-specific assets, however, or when the economic life of investments by the tenant is limited to the duration

\footnotetext{
1 In agricultural land leases a landowner rents land to a tenant, for instance for crop production or for grazing. Both parties might invest in inputs such as fertilizers or fences, of which the positive effects on production can stretch further than the contractually agreed lease duration.
} 
of the contract, shorter leases are to be preferred. Similarly, shorter durations help to decrease the risks related to market uncertainties, contract renegotiation and poor performance of the tenant. Bandiera (2007) adds the potential for providing incentives for non-observable investment effort to the advantages of longer contract durations, which comes at the cost of decreased flexibility and reduced potential for eviction threats by the landlord. ${ }^{2}$ The study further reveals that landlords who face higher transaction and monitoring costs indeed tend to offer longer contracts. Additionally, longer contracts are given for assets requiring more investments. Yoder et al. (2008) hypothesize that landlords are more likely to take care of investments in case of output-sharing contracts, for shorter contracts and for input investments with a longer economic life. Tenants, on the other hand, tend to invest in inputs with a shorter economic life, for non-output-sharing leases with cash-rent payments and when given longer contract durations.

Other evidence on contract durations has been discussed in work on coal contracts, gas markets and franchising. The results of a study by Kerkvliet and Shogren (2001) on the duration of coal contracts between utility buyers and supplying mines in the Powder River Basin largely support the previously mentioned insights from the transaction cost theory (i.e. higher transaction-specific investments and more certainty of transactions imply longer contract durations). Crocker and Masten (1988) also demonstrate that contract duration is based on a trade-off between period-by-period negotiation costs and costs related to rigidity of long-term contracts. The authors argue that the inclusion of contingent clauses to cover for uncertainties (e.g. regulatory interference) is expensive and difficult, while enforcement through judicial systems might also be costly and time-consuming. ${ }^{3}$ Contracting parties therefore often include unilateral options to accommodate for change in the course of the contractual relation. If these options are optimally designed, according to the authors, both the use of contracts and their duration will be positively affected. Reporting on evidence of a set of 145 franchise chains in Spain, Vázquez (2007) finds a negative correlation between contract duration and the exposure to free-riding and hold-up problems, ${ }^{4}$ since longer contracts guarantee franchisees a stream of quasi-rents while shorter contracts allow for an easier contract termination. The author also found that higher contracting experience of the franchisor generally leads to longer contracts.

\footnotetext{
2 Bandiera's study jointly analyzes contract duration and type of land tenancy agreements signed between 1870 and 1880 in Siracuse, Italy. A distinction is made between short- and long-term contracts on the one hand, and fixed-rent versus sharecropping (i.e. output sharing) contracts on the other.

3 Part of the literature on contract theory is devoted to the study of so-called incomplete contracts - which do not cover all possible contingencies - and is in many ways related to the literature on transaction costs (see e.g. Salanié, 1997).

4 The hold-up problem occurs when one of two players refuses to proceed with a jointly rewarding cooperation because of a fear for a resulting increase in the bargaining power of the other party. In a seaport setting such an increased bargaining power could for instance occur when a shipping line plans a major investment project in a dedicated hub which generates a substantial portion of the port's throughput (e.g. MSC in Antwerp).
} 
Table 1.

Conditions for concession length

\begin{tabular}{|c|c|c|}
\hline & Longer Duration & Shorter Duration \\
\hline $\begin{array}{l}\text { Investment-specific } \\
\text { conditions }\end{array}$ & $\begin{array}{l}\text { - High transaction-specific } \\
\text { investments by operator } \\
\text { - Landlord wishes to provide } \\
\text { incentives for (non-observable) } \\
\text { investment effort Evaluation of } \\
\text { value of assets invested by } \\
\text { operator is difficult } \\
\end{array}$ & $\begin{array}{l}\text { - High site-specific investments } \\
\text { of landlord } \\
\text { - Economic life of } \\
\text { transaction-specific investments } \\
\text { limited to contract duration }\end{array}$ \\
\hline $\begin{array}{c}\text { Conditions on } \\
\text { experience, performance } \\
\& \text { behaviour of parties }\end{array}$ & - More experienced parties & $\begin{array}{l}\text { High probability of poor } \\
\text { performance of operator } \\
\text { - High probability of free-riding } \\
\text { and hold-up problem }\end{array}$ \\
\hline $\begin{array}{l}\text { Contractual } \\
\text { conditions }\end{array}$ & $\begin{array}{l}\text { - High transaction/negotiation } \\
\text { costs } \\
\text { - Use of properly designed } \\
\text { contracts }\end{array}$ & $\begin{array}{l}\text { - High probability of contract } \\
\text { renegotiation } \\
\text { - Parties require high flexibility } \\
\text { - Landlord requires high } \\
\text { eviction threats }\end{array}$ \\
\hline
\end{tabular}

Source: own elaboration

Table 1 summarizes these insights from contract and transaction cost theory and rephrases them in terms of the contractual relation between a landlord/awarding authority and a terminal operator/bidder. In that perspective the conditions are grouped into investment-related factors, factors concerning experience, performance and behavior of the parties and contractual factors.

\subsection{Theory versus practice in European ports}

When comparing the economic theory as summarized in Table 1 with the results of the survey for ESPO (Notteboom, 2008), some theoretical factors are clearly supported by the European case, while for others no clear support is found. From the theoretic elements in Table 1 the investments made by operator and landlord seem to play a pivotal role in the determination of terminal concession durations in European ports. The results of the ESPO survey clearly indicate that in practice the duration mainly varies with the amount of the initial investment required, both from the terminal operator and the managing body of the port (Figure 2). Larger facilities also tend to have longer durations (Figure 1). Many of the other factors considered in Figure 2 have direct implications on the required investment levels, e.g. the type of terminal/commodity handled on the terminal, the level of dedicated layout/equipment at the terminal, the location of the terminal in the port and the status of the terminal site (greenfield site versus brownfield site). However, these other factors do not play a strong role in case of smaller terminals. 


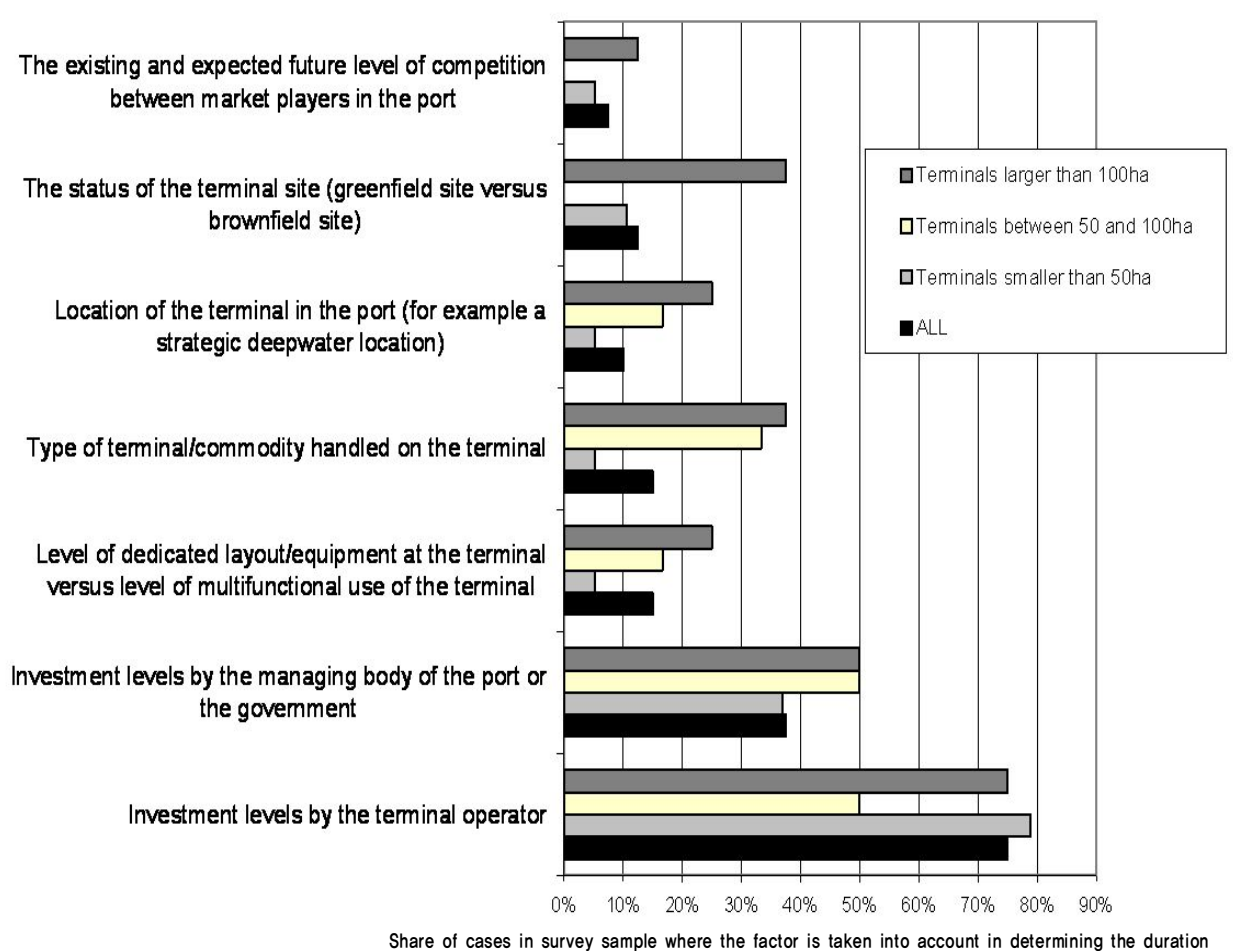

Figure 2. Survey results - criteria used for the determination of the contract term

The role of investment levels and return on investment (ROI) in the determination of the concession term is also confirmed by recent cases. For example, the market consultation document on the Saeftinghe Development Area, a planned new tidal dock in the Antwerp port, states that 'The duration of the concession shall be calculated on the basis of article 4 of the Terms and Conditions. ${ }^{5}$ For this purpose the investments and return on investment upon completion of these investments will be critical in determining the duration of the concession' (Antwerp Port Authority, 2008: 38). The Antwerp Port Authority uses a fork system to help determine the concession term (Table 2).

5 The 'Terms and Conditions for concessions in the Antwerp port area' form the basis of the area managers' concession policy and apply to all existing and future concessions awarded by the port authority. These terms and conditions form an integral part of the concession agreement and are applicable to all concessions, unless otherwise stipulated in the so-called special conditions. 
Table 2.

Fork system for the calculations of the concession term as used by the Antwerp Port Authority

\begin{tabular}{c|c}
\hline Investment fork & Term \\
\hline \hline Investment $>=375 \mathrm{EUR} / \mathrm{m}^{2}$ of arable land 6 & 40 years \\
\hline $225 \mathrm{EUR}<=$ investment $<375 \mathrm{EUR} / \mathrm{m}^{2}$ of arable land & 35 years \\
\hline $175 \mathrm{EUR}<=$ investment $<225 \mathrm{EUR} / \mathrm{m}^{2}$ of arable land & 30 years \\
\hline $150 \mathrm{EUR}<=$ investment $<175 \mathrm{EUR} / \mathrm{m}^{2}$ of arable land & 25 years \\
\hline $125 \mathrm{EUR}<=$ investment $<150 \mathrm{EUR} / \mathrm{m}^{2}$ of arable land & 20 years \\
\hline $100 \mathrm{EUR}<=$ investment $<125 \mathrm{EUR} / \mathrm{m}^{2}$ of arable land & 15 years \\
\hline $25 \mathrm{EUR} / \mathrm{m}^{2}<=$ investment $<100 \mathrm{EUR} / \mathrm{m}^{2}$ of arable land & 10 years \\
\hline $0 \mathrm{EUR} / \mathrm{m}^{2}<=$ investment $<25 \mathrm{EUR} / \mathrm{m}^{2}$ of arable land & Quarterly \\
\hline
\end{tabular}

Source: Antwerp Port Authority (see also Pallis et al 2008)

Theory and practice thus seem to agree that terminal operators who are willing to make more transaction-specific investments (or are stimulated to do so by the landlord port authority) should be given longer concession durations. Similarly, shorter contract length is expected when site-specific investments (e.g. in dredging and land reclamation works) by landlord port authorities become more substantial. While these principles will generally hold within seaports, in practice differences still seem to exist among seaports, as is illustrated in Figure 3. For a sample of 18 terminals across Europe, typical divisions of investments between operators and port authorities at the level of nine major investment categories are mapped against the minimum, median and maximum of the concessions' durations. It appears that durations are not always related to the distribution of investments between public and private parties, even when corrected for size differences. ${ }^{7}$

\footnotetext{
6 The total arable land is typically much smaller than the concessioned land as there are severe building restrictions on large parts of concessioned land.

7 Because the authors did not have access to actual investment amounts, terminal size was taken as a proxy and its correlation with concession duration appeared to be rather weak.
} 


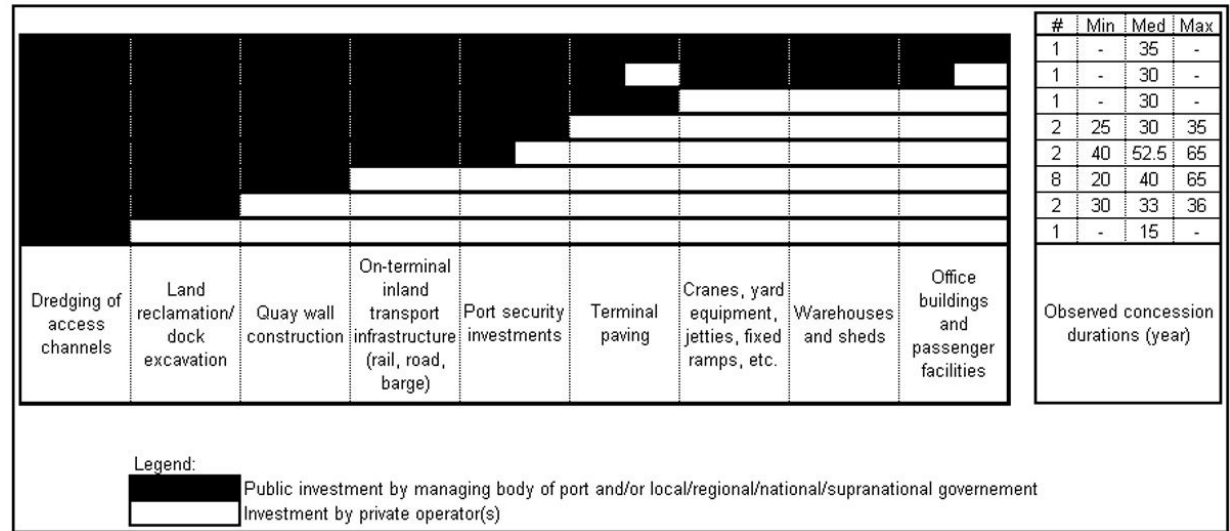

Source: Own elaboration based on survey results Notteboom (2008)

Figure 3. Concession duration and investment division 8

When landlord port authorities wish to provide incentives for (potentially unobservable) investment efforts by the operator, they might do so by providing longer concession durations or extensions to the original contract. This tends to be a factor of importance in practice as well. Many terminal award contracts (nearly $60 \%$ in the survey sample) contain stipulations on a possible prolongation of the terminal award beyond the official term. The most popular contract arrangements are:

- Clauses referring to the conditions for renewal of the terminal use after the end of the regular contract term (mentioned by $39 \%$ of the respondents who included renewal or extension clauses in the contract)

- Clauses referring to an extension of the contract term if the terminal operator makes additional investments during the regular contract term $(18 \%)$

- Clauses referring to interim evaluations (for example every five years) during the contract term. The continuation of the terminal use is subject to a positive evaluation during the interim evaluations $(18 \%)$.

Table 3 reveals that, in $37 \%$ of the survey cases, the port authority makes a possible extension of the contract term subject to a direct negotiation between the terminal operator and the managing body of the port at the end of the regular term. Such an arrangement is particularly common for medium-sized terminals. The port authorities opt for a public procedure in $32 \%$ of the cases. Such an arrangement is popular for smaller terminals. In some ports, the terminal operator can request a prolongation of the terminal contract based on major investments made by the operator throughout the contract term or in the last years of the contract term. Such requests are then examined by the port authority.

8 \# = number of projects in sample 
Table 3.

Possibilities to extend the duration of the contract

\begin{tabular}{l|c|c|c|c}
\hline & \multirow{2}{*}{ All } & \multicolumn{3}{|c}{ Size of terminal } \\
\cline { 3 - 5 } & & $<\mathbf{5 0 h a}$ & $\mathbf{5 0 - 1 0 0 h a}$ & $>\mathbf{1 0 0 h a}$ \\
\hline \hline What possibilities exist to extend the duration of the award contract? & & & & \\
Extension of the duration through a public procedure at the of the regular term & $32 \%$ & $44 \%$ & $17 \%$ & $13 \%$ \\
$\begin{array}{l}\text { Extension of the duration through a direct negotiation between terminal } \\
\text { operator and managing body of the port at the end of the regular term }\end{array}$ & $37 \%$ & $33 \%$ & $50 \%$ & $13 \%$ \\
Both of the above & $13 \%$ & $11 \%$ & $0 \%$ & $38 \%$ \\
None of the above & $18 \%$ & $11 \%$ & $33 \%$ & $38 \%$ \\
\hline & $100 \%$ & $100 \%$ & $100 \%$ & $100 \%$ \\
\hline
\end{tabular}

Economic theory furthermore expects the level of experience and reliability of the operator to influence contract length, as contracting with experienced and reliable partners reduces the risk of poor performance, free-riding and hold-up. As a result, the landlord authority foresees fewer eviction threats and will generally be willing to offer longer concession durations to experienced operators. Yet, we believe that in practice its impact on concession duration in established port systems is rather minor. During the awarding procedure port authorities are typically able to impose requirements (e.g. geographical and or functional experience, financial strength, etc.) on potential bidders in a so-called pre-bidding phase (see Notteboom et al., 2009, and Theys et al., 2010), which significantly reduces the need to adjust the concession length to operator characteristics. However, in case awarding authorities fear higher probabilities of renegotiation, durations might be shortened. Renegotiation of concessions is a serious issue which should be avoided, since it might easily offset the advantages obtained by a competitive awarding procedure (OECD, 2007). While researched in other sectors (e.g. Guasch, 2004; Guasch et al., 2008), so far little is known on the issue of renegotiation of terminal concessions in seaports (Theys et al., 2010).

Surprisingly, the survey also reveals that managing bodies of ports in the sample do not generally seem to take into account existing and potential competition between market players in the port (intra-port competition) when deciding on contract duration (Figure 2). In other words, the number of players in one specific terminal market segment inside the port area does not seem to have an impact on the contract term (the figures for large terminals are significantly higher though). Other factors that can play a role in the setting of contract durations relate to the compliance with the development policy of the port, land lease and other easement rights and the refurbishment of historical sites within the concession area. 
Concluding on the empirical support of the theory on concession durations it appears that investment-specific conditions are predominant in the determination of concession length in European seaports. While conditions on experience, performance and behavior of the parties might play a role in theory, we argue that in (European) practice such factors usually play a role in a specific (pre-qualification) phase of a typical concession procedure. In established port systems contractual conditions do not seem to influence concession durations a lot, although this could be different in less-developed port systems.

\section{Determining concession duration: methods and techniques}

The 2008 ESPO survey revealed that managing bodies of ports seem to have largely diverging approaches towards the general applicability of the method deployed to set the duration (Notteboom, 2008). About 57\% of the port authorities in the survey sample pointed out that the duration is determined ad hoc based on the specificities of the terminal under consideration. The remaining respondents indicated they deploy some kind of uniform formula or system to determine contract duration for all terminals in the port. This section provides an overview of techniques that can be used to calculate concession durations in seaports. Similar to the discussion on economic theory in Section 2, these methods have been developed in other sectors but can also be applied to terminal concessions.

Although we argued earlier that awarding authorities often grant concession extensions when certain conditions are fulfilled, we assume in the remainder of this paper - in line with the viewpoints of the European Commission - that extensions of the concession duration are not granted automatically. It does not necessarily imply that all investments should be made at the beginning of the concession period. It means that only foreseeable investments will be taken into account in the determination of the duration of terminal concessions. Additionally, we assume that the landlord port authority does not give any financial compensation to the private operator for the remaining (market) value of the immobile assets that change ownership at the end of the concession. The ESPO survey revealed that such financial compensations for remaining superstructure are not common practice in European seaports. Furthermore, they tend to transfer the risks related to overinvestment by the private sector to public entities and put a burden on the future exploitation of the terminal.

\subsection{Exogenous versus endogenous determination of a concession duration}

A first important decision for awarding authorities is the choice between an exogenous or endogenous procedure to calculate the duration of concessions. Various types of terminal awarding procedures exist, containing auction-alike and/or negotiation-based components (Theys et al., 2010). In general, the duration of the concession will be an exogenous factor 
in the awarding process: The awarding authority will decide upon the duration largely in advance, during a pre-bidding procedure, with potentially some negotiations between authority and candidate later on in the awarding process.

However, one could also design awarding procedures without a predetermined length, but based on the outcome of the competitive bidding procedure. An example of such an endogenously determined duration for infrastructure concessions is given by Engel et al. (2001), who propose a so-called least present value of revenue from tolls (LPVR) auction to select the most suitable candidate for a highway franchise. In an LPVR auction the right to construct and exploit a particular highway section is granted to the private operator who requires the lowest discounted sum of tolls. The duration of the concession is then (endogenously) determined as the period that is necessary to receive the proposed LPVR. This concession duration is in fact variable, as it is automatically extended or shortened in case of negative respectively positive market (or revenue) evolutions. Hence, in such a system the operator always receives exactly his proposed LPVR (i.e. nothing more or less). Engel et al. (2001) prove that under certain circumstances LPVR auctions are optimal for highway franchising programs.

Despite its innovation, a mere extrapolation of the LPVR system to terminal concession durations in seaports seems less appropriate. First, when concession length is automatically adjusted to evolutions in the market, the market risk is (almost) entirely transferred from the private to the public sector. This is generally not in line with the goals of PPPs. Although this disadvantage could be remedied by defining conditions under which the duration would be extended to meet LPVR versus situations where the operator should bear the risks, there are additional issues with the application of this "variable duration" concept. Stevedores usually operate in much more competitive markets than franchisees of highway sections. While the latter face demand as largely 'given', terminal operators are encouraged to make commercial efforts and hence tend to have more impact on the demand for their port. Market evolutions are therefore no longer purely exogenous and it would be nearly impossible to evaluate whether or not certain changes in revenues are due to operators themselves. The application of an LPVR auction with adjustable concession duration (and hence - under certain circumstances - guaranteed revenues) could therefore lead to performance decrease, lack of innovation and excessively long occupation of strategically well-located terminals. Although an adaptation of the LPVR auction for use in seaports would be an interesting avenue of research, we will focus in the remainder of this paper on exogenously determined concession durations.

\subsection{A classification scheme for exogenously determining a concession duration}

The number of papers that explicitly deal with calculation methods for concessions is small and mainly situated in the field of construction engineering, and more specifically in research on PPPs for infrastructure projects (mainly Build-Operate-Transfer or BOT), such 
as bridges and tunnels. To the best of our knowledge, no papers presenting techniques tailored to terminal concessions in seaports have been published. Despite the limited number of papers on the topic, however, a classification based on three dimensions can be made (Table 4).

In a first dimension the classification scheme considers the number of stakeholders whose interests are explicitly included in the calculations of the concession term. Methods with a unilateral character focus on the interests of one party, typically the terminal operator or the port authority. The objective of the calculations is then the maximization of some (discounted) value measure related to different concession durations from the viewpoint of the sole stakeholder considered. On the other hand, when the concession term is determined on the basis of a trade-off, a balance is sought between the interests of the different stakeholders. In a two-dimensional trade-off determination, the interests of the port authority and private operator are included in the analysis, while a three-dimensional trade-off method additionally considers port users.

A second dimension in the classification scheme distinguishes among point and interval determinations of concession length. The outcome of a point calculation is one value for the duration of the terminal concession (rounded or not), whereas an interval determination gives an interval of durations that is acceptable to the stakeholders involved. While the choice of the exact duration of the concession contract from the calculated interval can be based on past practices or rounding to a "convenient" number, it will be most useful in negotiations between stakeholders.

Lastly, calculation methods might be stochastic or deterministic, depending on whether or not their underlying models contain random variables (see e.g. Winston, 2004, or Hillier and Lieberman, 2005, for a discussion). In a deterministic model inputs are assumed to be known with certainty and the same set of inputs always leads to the same model outcome. Stochastic models treat inputs probabilistic, as random variables, with their values (or random variates) selected randomly from probability distributions. Hence, outcomes are also random and estimated by probability distributions.

The deterministic or stochastic character of methods is closely related to the way that risk and uncertainty are (or can be) embedded in the calculations. When bidding for terminal concessions, operators expect to make certain investments in superstructure on the basis of assumptions on factors as inflation, exchange rates and raw material prices. Similarly, expected operational costs depend, among others, on developments in energy prices and labor costs, while expected revenues vary greatly with scenarios on future cargo throughput levels. Cash flows are therefore expected values that should be obtained by taking into account all possibilities weighted by their probabilities and are to be discounted by the project's cost of capital, which contains a risk premium on top of the risk-free return (Armitage, 2005).

Deterministic models are most closely linked to this way of dealing with risk and uncertainty. In such models a given set of input parameters (or a scenario) always leads to the same outcome. Since input parameters are expected values and thus dependent on the 
probabilities of future events, decision makers might want to construct a set of scenarios based on different assumptions (or probabilities) of future events. Such deterministic simulation (or scenario planning) considers the different outcomes over the set of scenarios and allows decision makers to perform "what if" analyses (e.g. what if throughput lies $\mathrm{x} \%$ below expectations). If wished, it can also be used to establish certain duration intervals that could be useful during negotiations on concession length. Obviously, when the set of evaluated scenarios is a singleton, calculations are based on a sole fixed scenario to determine concession length, but even such method takes uncertainty into account through expected values and the discount factor.

Models on the basis of stochastic simulation do not input expected parameter values, but embed risk and uncertainty by means of probability distributions of random input variables. Their scenario space is, therefore, given rather implicitly, as each realization (or run) of the model could be considered as a particular scenario. Stochastic duration calculation models thus deal more directly with risk and uncertainty by means of the probabilistic character of their inputs, but are considerably more complex because estimating probability distributions on inputs is generally hard. Additionally, discount factors containing risk premiums should be adjusted in order to avoid double-counting of risk in the analysis.

\subsection{Discussion of techniques}

Generic methods for investment appraisal form the backbone of nearly all calculation techniques with respect to concession durations. In its most basic form (see class A in Table 4) the determination of terminal concession durations might be based solely on the solution of one scenario of such a model. Net present value (NPV) and internal rate of return (IRR) prove to be most useful, ${ }^{9}$ with the former given by the mathematical expression $N P V(t)=-1_{0}+\sum_{i=1}^{t}\left[F_{i} \cdot(1+r)^{-i}\right]$, with $t$ the operational duration of the concession, $F_{i}$ the net cash flows in each period, $I_{0}$ the initial investments, $r$ the discount factor and $N P V(t)$ the net present value of the project corresponding to a duration $t$. In the same vein the IRR is found as the return $r$, for a given $t$, for which $N P V(t)=0$. As a company's main objective is to create value, the returns on any of its investments should exceed their corresponding hurdle rates. The latter relate to the company's cost of capital, but might be adjusted with a risk premium in case the project-specific risk is deemed high. Therefore, for operators willing to invest in a terminal concession its minimally required operational duration $t_{\min }$ should be sufficiently long, so that $N P V\left(t_{\min }\right) \geq 0$ at the

\footnotetext{
9 Other methods for investment appraisal such as payback period (PP) and accounting rate of return (ARR) are less suitable for the determination of concession durations. PP ignores the size of investments and cash flows, as well as the time value of money and opportunity costs. ARR has a strong accounting bias and fails to include relevant cash flows (Quiry et al, 2005).
} 
hurdle rate $r_{\min }$. Equivalently, the concession's IRR should exceed $r_{\min }$ for the minimum (operational) duration t_min. If those conditions are not fulfilled for a potential private partner, the company will not (and should not) proceed with investing in and operating the terminal. On the other hand, landlord port authorities should beware of excessive ex-post rents for the operator to whom the concession is given, since the awarding of terminal concessions is a typical case of 'competition for the market' (see Theys et al., 2010) as proposed in cases where 'competition in the market' fails (Demsetz, 1968). The authorities can prevent rent-seeking by the operator by granting a concession with length exactly equal to $t_{\text {min }}$. Note, however, that capital costs and required risk premiums can differ among operators, so that hurdle rates $r_{\min }$ and minimally required operational concession durations $t_{\text {min }}$ might also differ.

A potential disadvantage of the basic NPV approach for calculating concession durations is that the specific point duration leaves little room for negotiations. One may therefore opt for an interval of durations that is acceptable to both parties. Where the objectives of only one stakeholder are included (see class $\mathrm{C}$ in Table 4), this could be obtained by means of scenario planning. Such scenarios can for instance be based on best and worst expected net cash flows, assumptions on the investments and hurdle rate ranges. The latter is particularly useful in light of the hurdle rate differences among operators, which are typically unknown to awarding authorities. When objectives of multiple stakeholders are considered (see class D in Table 4), an interval could be constructed with a lower bound duration below which the operator will not accept to invest because his expected return is smaller than the hurdle rate, and an upper bound duration above which the awarding authority will no longer be willing to grant the concession in order to prevent excessive ex-post rents. Shen et al. (2002) were the first to present a deterministic technique that balances private and public partners' interests in BOT infrastructure projects, later extended by Shen and $\mathrm{Wu}(2005)$ to the stochastic case. The lower bound on concession duration is obtained through the operator's hurdle rate. As a condition for the upper bound duration the authors claim that from the public partner's point of view the present value of expected net cash flows realised between the end of the concession - that is when operations are transferred to the government - and the end of the economic life of the investment has to be positive. Such a condition is not very useful in a seaport setting because landlord port authorities generally do not wish to continue operations themselves at the end of the concession period. ${ }^{10}$ It is therefore recommended to base the calculations on minimum and maximum NPV or IRR, such as presented in Zhang and AbouRizk (2006) for concessions for public works and services.

10 Although the ownership of immovable assets in many seaports transfers to the managing body upon termination of the concession, contracts typically include clauses that require the terminal operator to restore the land to its original condition (i.e. demolish buildings, sheds, warehouses, etc.) if authorities wish so. Therefore, any such related costs incurred after the termination of the concession are usually the responsibility of the operator. 
If perception of risk and uncertainty is high, decision makers might wish to turn to stochastic simulation techniques as an alternative to scenario sampling. Both NPV-based and more complex duration calculation techniques have stochastic variants (see classes E-H in Table 4). As model input becomes random, so will be model outcome $T_{\min }$. For a given confidence level a a point estimate $t_{\min }$ for concession length is therefore found where $P\left(T_{\min }<t_{\min }\right)=\alpha$. Ng et al. (2007a) suggest such an approach for optimizing the concession period of PPP schemes. Alternatively, the outcome distribution might lead to an interval for negotiations, for instance through a minimum and maximum $\alpha$.

Lastly, some more exotic techniques have been proposed for the case of multiple stakeholder objectives. While originally suggested for stochastic point estimates by $\mathrm{Ng}$ et al. (2007b) and Shen et al. (2007), these methods based on respectively fuzzy set and bargaining theory could in essence also be applied when deterministic and or interval techniques are desired by varying the number of scenarios or realizations (see classes B, D, $\mathrm{F}$ and $\mathrm{H}$ in Table 4).

\subsection{Selecting a technique for determining a contract duration}

Depending on the circumstances some of the techniques presented in Table 4 will be more useful than others. The decision framework given in Figure 4 helps managers and government officials decide on the most appropriate method on the basis of three questions that are directly related to the categories of the classification scheme. 
Determining terminal concession durations in seaports:

theoretical considerations, applicable techniques and current practices

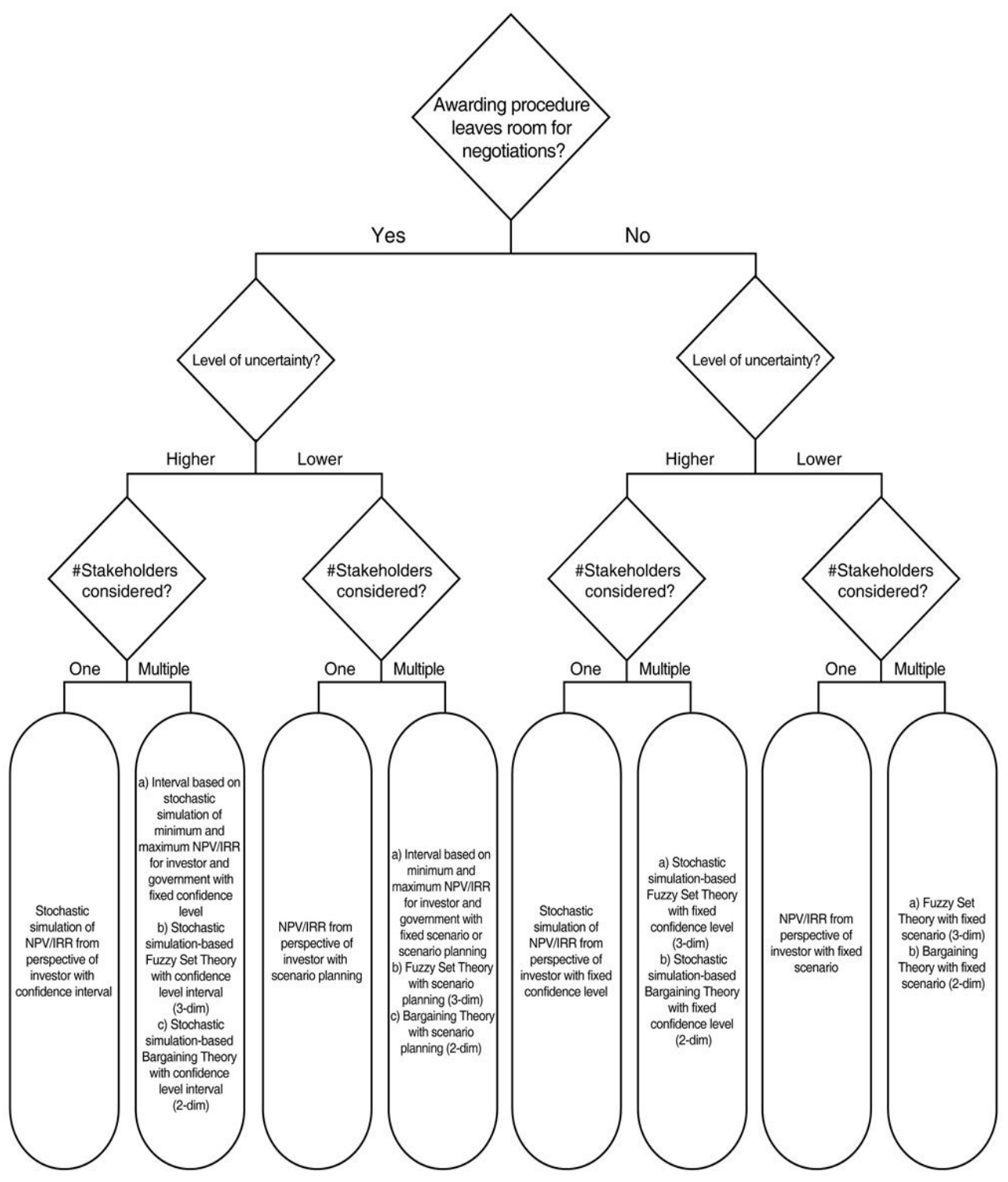

Figure 4. Decision tree for the determination of concession durations 
Table 4.

Classification scheme for exogenously determined concession length

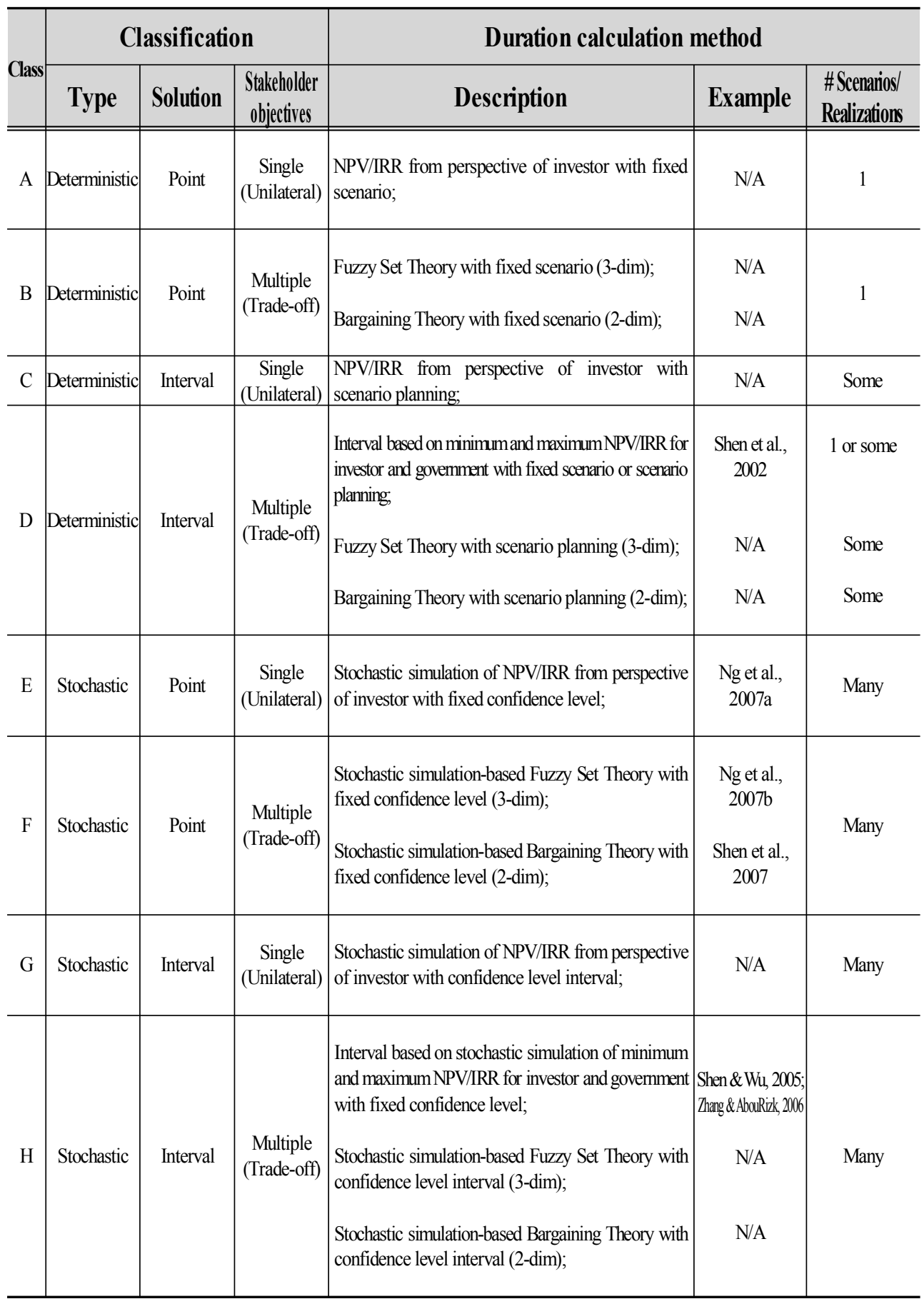


First of all, the flexibility of the awarding procedure should be considered. In case the concession duration is nonnegotiable, point techniques might be more appropriate. Interval methods are typically more suitable in situations where parties engage in negotiations on concession length. Interestingly, in European ports such duration negotiations seem to occur, but are not predominant. The ESPO survey (Notteboom, 2008) stated that in $61 \%$ of the terminal projects the term of the contract was or is preset by the managing body of the port. In the remaining cases the term was the result of a negotiation between terminal operator and the managing body of the port. Occasionally, the latter might opt to leave it up to the bidder to indicate the duration that he requires.

Decision makers should then evaluate whether or not the project is subject to considerable uncertainty or can be forecasted accurately. Higher levels of uncertainty suggest the use of techniques based on stochastic simulation, but this comes at a price of increased complexity. In other cases the use of deterministic variants might be sufficient.

Finally, one also has to assess the number of stakeholder types (e.g. private operators, government or port users) of which the objectives will be taken into account. Again it should be borne in mind that complexity rises with the number of stakeholders considered.

\section{Discussion on the importance of concession length}

The duration of concession agreements is of crucial importance both to terminal operators and managing bodies of ports, since concession length might have an impact on the market structures in seaports. The terminal operators are obviously in favor of long concessions (FEPORT, 2005). In general, long-term agreements allow private port operators to benefit from learning-by-doing processes and to achieve a reasonable ROI. Managing bodies of ports try to find a balance between a reasonable payback period for the investments made by terminal operators on the one hand and a maximum entry to potential newcomers on the other. As long-term agreements limit market entry, intra-port competition will only take place among incumbent operators. However, even when concession periods are long, new players can still enter the market either through a merger or acquisition of a local operator or when a long-term concession or lease of a new terminal expansion is allocated to them. Managing bodies of ports can even build safety valves in the contract, so as to make the terminal available to other candidates in case the existing operator does not meet specific performance thresholds. Obviously the duration of terminal concessions is also of prime importance to port users. Shorter durations will force terminal operating companies to impose higher handling rates to port users, which makes the operator less competitive than players with more favorable concession terms. Alternatively, restricted intra-port competition resulting from longer concession durations might also confront port users with higher charges. 


\section{Textbox 1}

Case description

The (hypothetical) case relates to a medium-sized container terminal of 16 ha with a capacity of $600,000 \mathrm{TEU}$ which is equipped with five ship-to-shore gantry cranes. In the base case total investments made by the company amount to 114 million euro, including both (new) equipment and non-equipment related costs such as mobilization, civil works, offices and sheds. $80 \%$ of the initial investments are assumed to be eligible for linear depreciation over a period of 15 years. The tax rate in the base scenario is fixed at $25 \%$ and the operator is required to pay a variable royalty of 10 euro per TEU handled and a fixed concession fee of 5 euro per $\mathrm{m}^{2}$ of terminal surface. Capacity utilization is expected to increase linearly over the first eight years of the concession, after which the terminal operates at capacity (Figure 5). Revenue and EBIT estimates amount to 115 respectively 42.66 euro per TEU. Fixed and variable costs are based on numbers given by Drewry (1998), but verified and actualized by industry experts (Figure 6). To reduce the impact of high fixed (labor) costs in the initial years of operations, it is assumed that operators gradually increase the labor force over that period. Furthermore relevant alternative scenarios are constructed on the basis of variations in throughput (Figure 5) and revenue, royalties, concession fees, tax rate, operational costs and investment levels (Figure 7).

Governments and awarding authorities can strongly influence the private partner's ROI through various parameters of the concession contract, including concession length. Figure 7a maps an operator's ROI as a function of the operational duration of the terminal concession for the case described in Textbox 1.11 The resulting isocost-alike curves are asymptotically bounded, implying that ROI converges to a (case-specific) maximum return when duration approaches infinity. Higher hurdle rates thus require longer concessions, but the marginal return for the terminal operator tends to stabilize for longer durations. This occurs considerably faster for higher revenue per TEU ratios. However, concession duration extensions beyond the common [20, 30]-year duration range seem to have little impact on ROI. If the ROI of such a concession project falls below an operator's hurdle rate, not much remedy should be expected from a length increase. These duration insights tend to support the EC's past proposal of imposing a 30-year upper limit to concession length. Still, we believe that considering concession durations on a case-by-case basis, including expectations on achievable revenue, EBIT and the level of competition in the seaport range, is the right track to follow in view of preventing excessive extensions with

11 Reliable and comparable figures on profit margins, operational and investment costs in the container terminal industry are hard to find and depend on local practices and the port range under consideration (see e.g. the large variation given in Drewry, 2004). Yet, sensitivity analyses on input parameters confirm the observations made for the base case. 
minimal impact on ROI. If the concession agreement does not include stipulations on the conditions for a potential renewal and or extension of the concession, however, the concessionaire will typically cease all investments in the last years of the concession. This can lead to lower terminal efficiency and a suboptimal use of the land. Clauses regarding extendable and or renewable concessions result in a bidding procedure that offers a comparative advantage to the existing concessionaire vis-à-vis potential entrants. This existing concessionaire is likely to have an advantage because of his experience, market knowledge, and an existing customer base. Therefore, port authorities have to make a trade-off between securing market entry and binding efficient terminal operators.

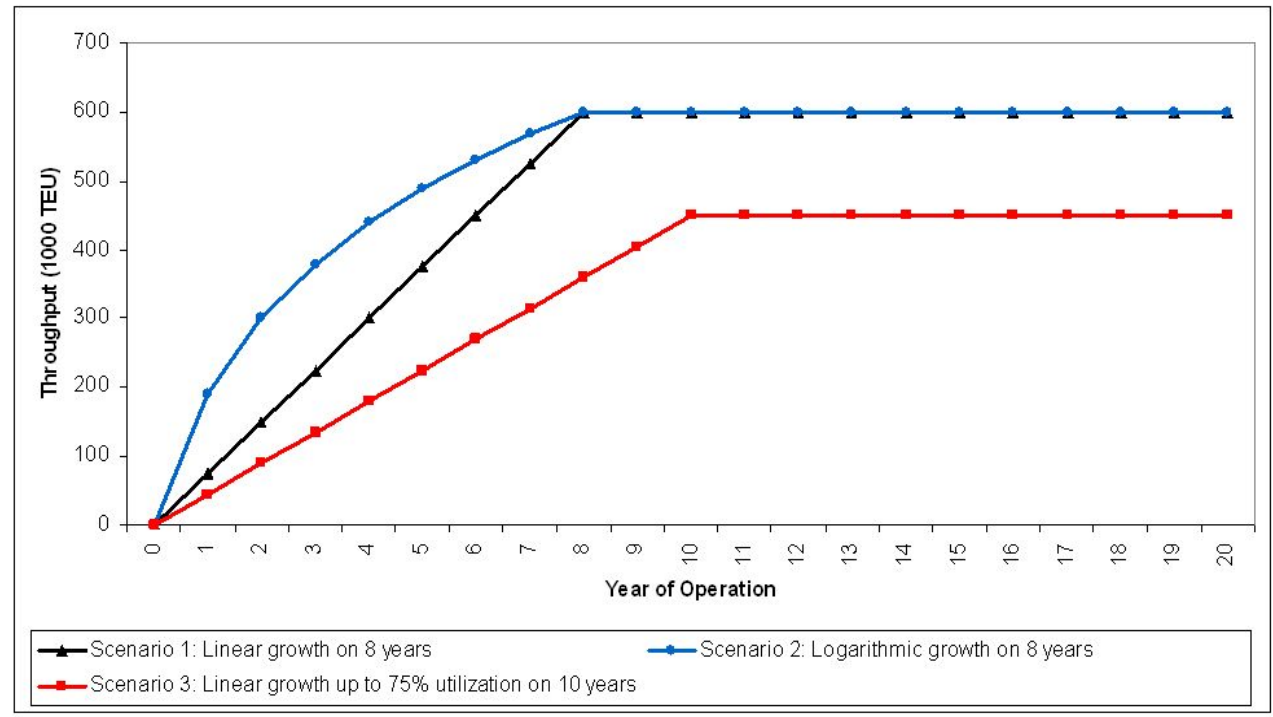

Figure 5. Throughput scenarios

Awarding authorities might influence the ratio between ROI and terminal concession durations through their decisions on the concession fee structure. Figure $7 \mathrm{~b}$ shows that increases in royalties and fixed fees both have a negative effect on the obtained ROI for a given concession duration, but the former tend to cause a proportionally stronger decline as a result of their direct impact on variable costs. The concession length required to meet a certain hurdle rate might therefore increase substantially when the use of land is made more expensive and operators are unable to pass these additional costs along to the terminal users. Taxation has similar effects (Figure 7c). 

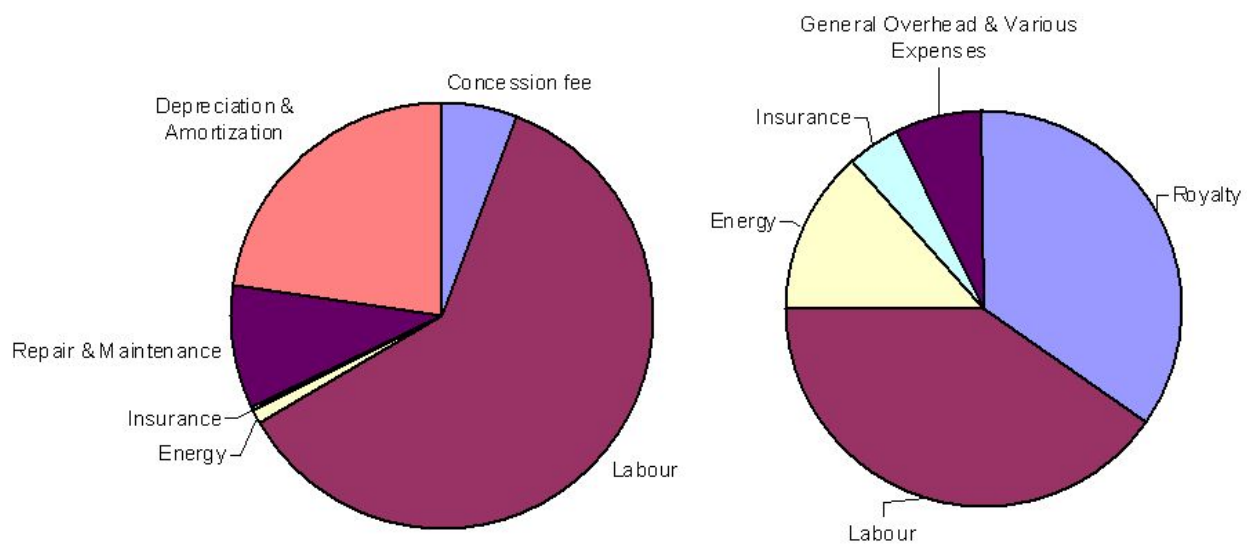

Source : Based on Drewry (1998) and input from industry experts

Figure 6. Fixed cost distribution per year (left) and variable cost distribution per TEU (right) for a hypothetical terminal

Operational costs and investment division also influence the ROI-duration relation (Figure 7d). Less efficient operators will require longer concessions under similar conditions as operational costs directly impact on the operator's cash flow stream. Awarding authorities might therefore provide incentives to increase efficiency by using cost benchmarks in the calculation of concession durations. Either inefficient operators will be no longer interested in such concessions because their expected ROI levels lie beneath their hurdle rates, or these operators will have to improve their operational efficiency. The importance of investments in seaport terminals has been underlined earlier in this paper (see also Dooms and Verbeke, 2006). Since the level of investments is positively correlated to the required concession length, over- and (more likely) underestimations of investment costs can have a considerable impact on duration. Incorrect investment estimations regularly occur in large infrastructure projects and authorities in particular seem to be rather optimistic in the estimation of the required budgets for projects (see e.g. British Department for Transport, 2004; Flyvbjerg et al., 2002; 2003; 2004). Operators, on the other hand, have an incentive to overestimate their investment levels when these investments are considered by the port authority as determinants of contract length, because such practice might lead to longer concessions (Figure 7e). 
theoretical considerations, applicable techniques and current practices

A

Base Case

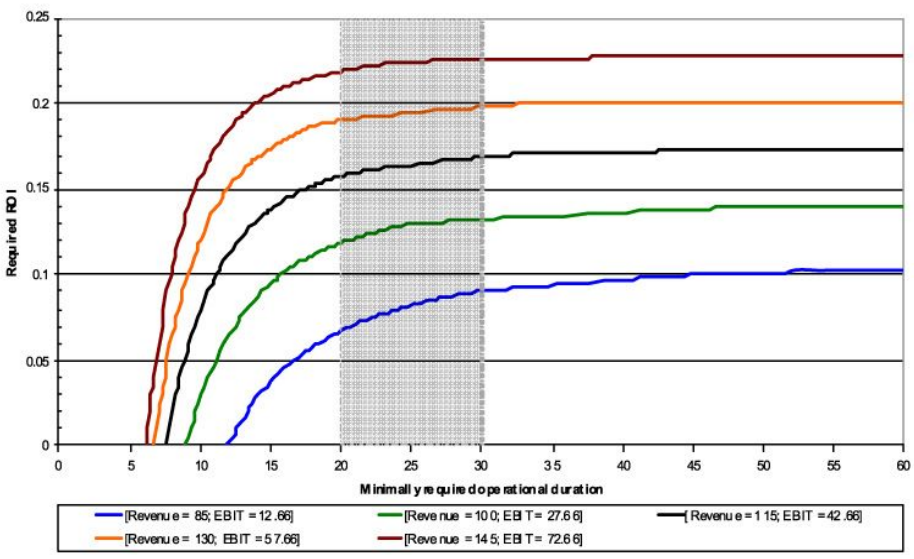

B

Sensitivity Royaty \& Conœssion Fee

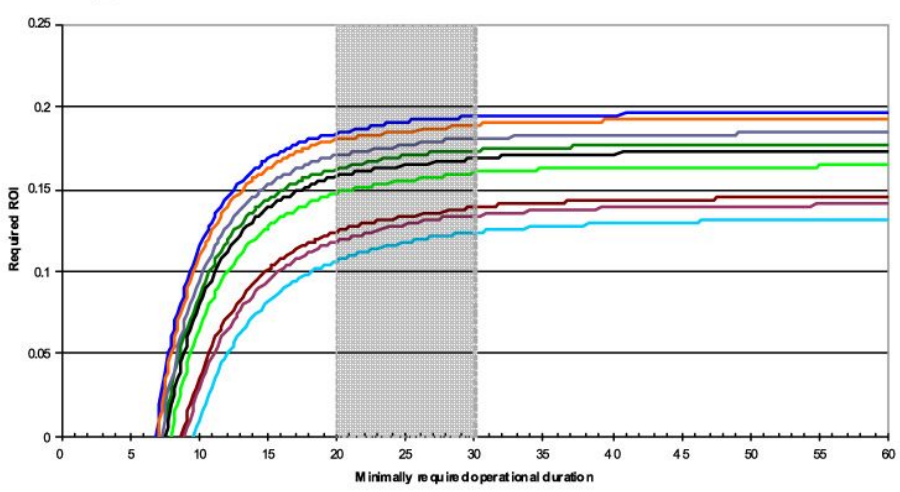

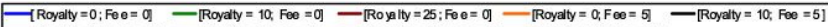

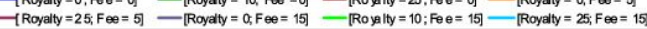

C

Sensifivity Taxes

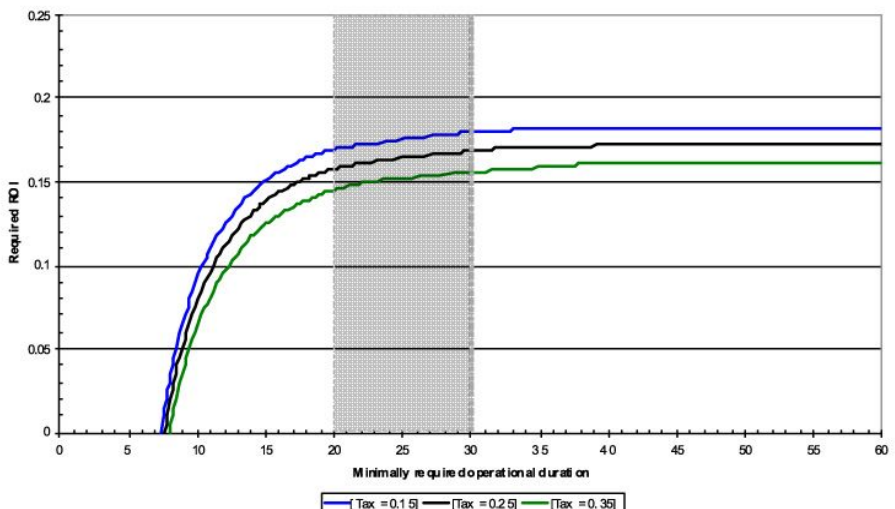

—Tax $=0.15$ - 

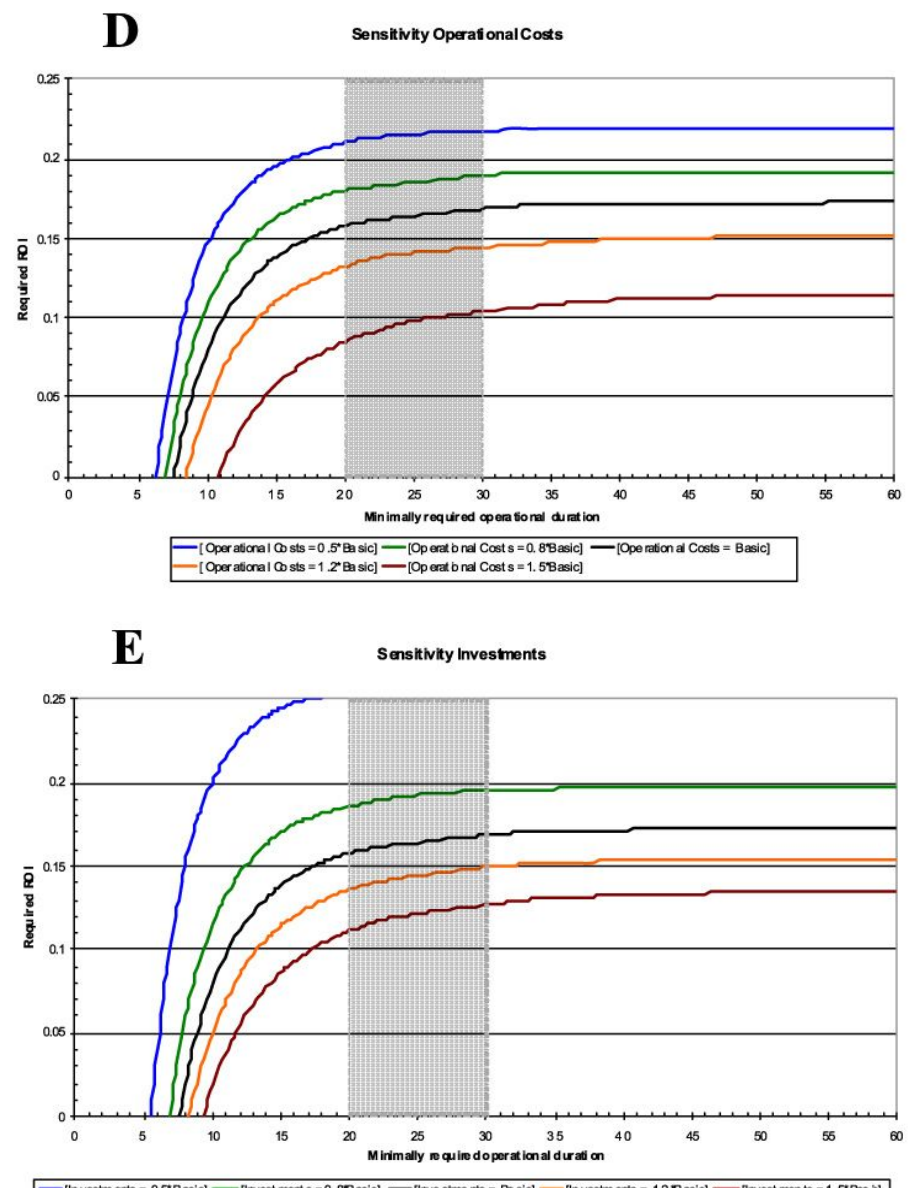

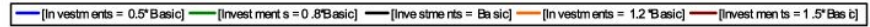

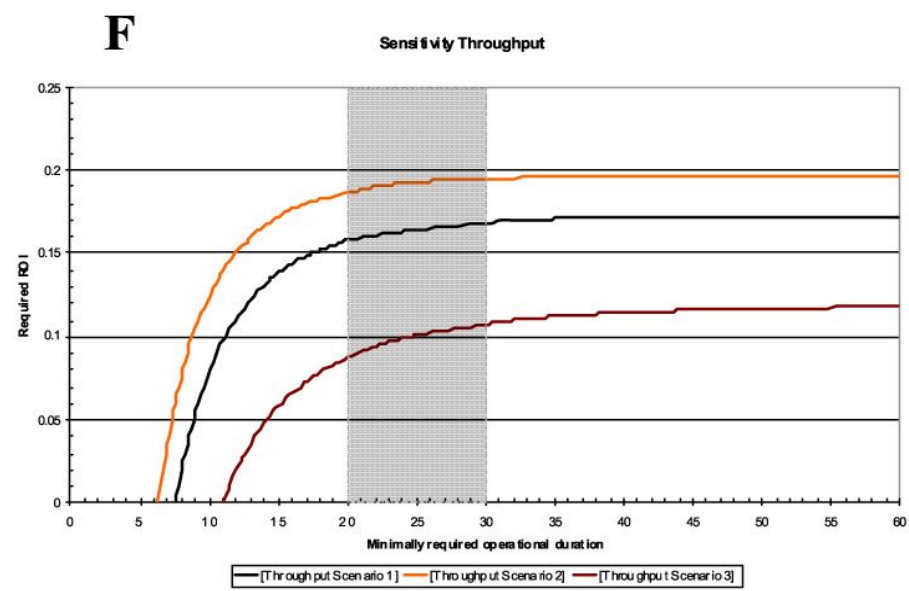

Figure 7. ROI as a function of operational duration for various parameter values 
Lastly, concession durations and resulting return levels are also affected by factors that often fall beyond the control of both parties. Figure $7 \mathrm{f}$ depicts the duration-ROI curves for the throughput scenarios of Figure 5. Higher throughput levels clearly lead to higher returns for a given duration and, conversely, a lower required concession length for a given hurdle rate. Uncertainties in throughput could be further analyzed by a technique based on stochastic simulation with throughput as a random variable (e.g. estimated as a triangular distribution with best and worst case deviations of $20 \%$ of the average). The resulting risk typically induces a shift of the ROI-duration curve to the right. Awarding authorities might, however, reduce such uncertainties by guaranteeing certain minimum revenue in case actual throughput drops below a certain proportion of the expected throughput. ${ }^{12}$ While such mechanisms are less suitable for projects with shorter duration, they could reduce the minimum concession length substantially for long-term contracts.

\section{Conclusions}

This paper discussed the duration of terminal concessions in seaports and illustrated the importance of determining an appropriate concession length for public and private parties. The paper applied insights from studies on the duration of contracts, leases and concessions in other sectors to PPPs in seaports. The economic theory on contract length was then linked to empirical evidence on durations of terminal concessions in Europe. Both theory and practice confirm that investment-specific conditions (including the investment division among private operator and public authority) are key elements in the determination of concession durations, although differences among ports still exist. Experience, performance and the behavior of the parties in the PPP play a role in theory, but usually not in practice. In European ports such factors are typically included in the awarding procedure itself. Contractual issues do not seem to influence concession duration much either, but this might be different in less-developed port systems.

Another contribution of this paper relates to the proposed classification scheme of calculation techniques for the duration of terminal concessions, based on three dimensions. A first dimension deals with point versus interval calculations. The former are most suitable in situations where authorities decide alone on concession length, while duration intervals are typically preferred when contract duration is determined on the basis of negotiations between public and private partners. A second dimension classifies techniques on the basis of the number of stakeholders considered (objectives of one versus multiple partners). A third dimension distinguishes among deterministic and stochastic techniques, with the latter being particularly useful in situations with high risk and uncertainty. Additionally, a decision framework was suggested to help decision makers in choosing the most appropriate approach.

12 Such practices are common in Asian countries. In Korea, for instance, the inclusion of a government guarantee for any drops below $90 \%$ of expected revenue was standard practice in major infrastructure projects. Above-average profits, however, are limited as well. 
The paper also pointed to the differing interests between operators and authorities when setting concession length. The former are obviously in favour of longer concessions, while the latter are faced with a trade-off between securing market entry and binding efficient terminal operators. Additionally, a case study for a medium-sized container terminal demonstrated the strong influence that governments and awarding authorities might have on the relationship between concession duration and operators' ROI. Besides company- and project-specific factors such as investment levels and operational costs, decisions on taxation, potential revenue guarantees and concession fee structure will impact this relationship and can, therefore, make private investments in the port industry more or less attractive for a given hurdle rate.

Although an endogenous (auction) technique was briefly discussed, this paper considered the determination of concession length as exogenous vis-à-vis the awarding procedure. A more in-depth study of the applicability of an (adapted) auction-alike structure to set concession duration endogenously remains a promising avenue for further research. Additionally, it would be interesting to consider the impact of duration along with other concession parameters on inter- and intra-port competition.

\section{References}

Antwerp Port Authority. 2008. Market Consultation: Saeftinghe Development Area, Antwerp.

Armitage, S. 2005. The cost of capital - Intermediate theory, Cambridge: Cambridge University Press.

Bandiera, O. 2007. Contract duration and investment incentives: evidence from land tenancy agreements, Journal of the European Economic Association 5(5): 953-986.

British Department for Transport. 2004. Procedures for dealing with optimism bias in transport planning, Guidance document, Report No. 58924, 61 p.

Cheung, S. 1969. Transaction costs, risk aversion, and the choice of contractual arrangements, Journal of Law and Economics 12: 23-42.

Crocker, K.J., and Masten, S.E. 1988. Mitigating contractual hazards: unilateral options and contract length, RAND Journal of Economics 19(3): 327-343.

Demsetz, H. 1968. Why regulate utilities?, Journal of Law and Economics 11: 55-65.

Dooms, M., and Verbeke, A. 2006. The financing structure of large-scale, seaport development projects: a comparative analysis of recently completed and planned projects in the European Union, Proceedings of the IAME 2006 Conference, Melbourne, Australia.

Drewry. 1998. North European container ports: A '\$2 billion plus' industry adapts to change, Drewry Shipping Consultants, London, 208 p. 
Drewry. 2004. Annual review of global container terminal operators, Drewry Shipping Consultants, London, $118 \mathrm{p}$.

Engel, E.M.R.A., Fischer, R.D., and Galetovic, A. 2001. Least-present-value-of-revenue auctions and highway franchising, Journal of Political Economy 109(5): 993-1020.

Engel, E.M.R.A., Fisher, R.D., and Galetovic, A. 2004. How to auction a bottleneck monopoly when underhand vertical agreements are possible, Journal of Industrial Economics 52(3): 427-455.

European Commission. 2004. Proposal for a Directive of the European Parliament and of the Council on market access to port services, Brussels, COM. 2004. 654.

FEPORT. 2005. FEPORT Position paper presented at the public hearing of the European Parliament and the European Commission, FEPORT, Brussels.

Ferrari, C., and Basta, L. 2009. Port concession fees based on the price-cap regulation: A DEA approach, Maritime Economics and Logistics 11(1): 121-135.

Flyvbjerg, B., Holm, M.K.S., and Buhl, S.L. 2002. Underestimating costs in public works projects: error or lie?, APA Journal 68(3): 279-295.

Flyvbjerg, B., Holm, M.K.S., and Buhl, S.L. 2003. How common and how large are cost overruns in transport infrastructure projects?, Transport Reviews 23(1): 71-88.

Flyvbjerg, B., Holm, M.K.S., and Buhl, S.L. 2004. What causes cost overrun in transport infrastructure projects?, Transport Reviews 24(1): 3-18.

Guasch, J.L. 2004. Granting and renegotiating infrastructure concessions: doing it right, World Bank, Washington, D.C.

Guasch, J.L., Laffont, J.J., and Straub, S. 2008. Renegotiation of concession contracts in Latin America - Evidence from the water and transport sectors, International Journal of Industrial Organization 26(2): 421-442.

Hillier, F.S., and Lieberman, G.J. 2005. Introduction to operations research, 8th Edition, New York: McGraw-Hill.

Juan, C., Olmos, F., Trinidad, C., and Pérez, J.C. 2004. Concession agreements in the shipping industry, Real Options: Theory Meets Practice Conference Proceedings; 17-19 June, Montréal, Canada.

Kerkvliet, J., and Shogren, J.F. 2001. The determinants of coal contract duration for the Powder River Basin, Journal of Institutional and Theoretical Economics 157: 608-622.

Ng, S.T., Xie, J., Cheung, Y.K., and Jefferies, M. 2007-a. A simulation model for optimizing the concession period of public-private partnership schemes, International Journal of Project Management 25: 791-798.

Ng, S.T., Xie, J., Skitmore, M., and Cheung, Y.K. 2007-b. A fuzzy simulation model for evaluating the concession items of public-private partnership schemes, Automation in Construction 17: 22-29. 
Notteboom, T. 2007. Concession agreements as port governance tools. In: M. Brooks and K. Cullinane (eds.) Devolution, port governance and performance, Elsevier, pp. 449-467.

Notteboom, T. 2008. The awarding of seaport terminals in Europe: results from the ITMMA survey commissioned by ESPO, University of Antwerp, $28 \mathrm{p}$.

Notteboom, T.E., Theys, C., Pallis, A.A., and De Langen, P.W. 2009. The economics behind the awarding of terminals in seaports: Economic issues in the pre-bidding phase, paper presented at the 2009 IFSPA Conference, Hong Kong.

OECD. 2007. Policy roundtable on concessions - background note, OECD, Paris.

Pallis, A.A., Notteboom, T.E., and De Langen, P.W. 2008. Concession agreements and market entry in the container terminal industry, Maritime Economics \& Logistics 10(3): 209-228.

Quiry, P., Vernimmen, P., Dallocchio, M., Le Fur, Y., and Salvi, A. 2005. Corporate finance: theory and practice, John Wiley \& Sons, Chichester, $1030 \mathrm{p}$.

Salanié, B. 1997. The economics of contracts, Cambridge: MIT Press.

Shen, L.Y., Li, H., Li, Q.M. 2002. Alternative concession model for build operate transfer contract projects, Journal of Construction Engineering and Management 128 (4): 326-330.

Shen, L.Y., Wu, Y.Z. 2005. Risk concession model for build operate transfer contract projects, Journal of Construction Engineering and Management 131(2): 211-220.

Shen, L.Y., Bao, H.J., Wu, Y.Z., Lu, W.S. 2007. Using bargaining-game theory for negotiating concession period for BOT-type contract, Journal of Construction Engineering and Management 133(5): 385-392.

Theys, C., Notteboom, T.E., Pallis, A.A., De Langen, P.W. 2010. The economics behind the awarding of terminals in seaports: towards a research agenda, Research in Transportation Economics, forthcoming.

Vázquez, L. 2007. Determinants of contract length in franchise contracts, Economics Letters 97: 145-150.

Winston, W.L. 2004. Operations research: applications and algorithms, Belmont: Brooks/Cole-Thomson Learning.

Ye, S., Tiong, R.L.K. 2003. The effect of concession period design on completion risk management of BOT projects, Construction Management and Economics 21: 471-482.

Yoder, J., Hossain, I., Epplin, F., Doye, D. 2008. Contract duration and the division of labor in agricultural land leases, Journal of Economic Behavior \& Organization 65: 714-733.

Zhang, X., AbouRizk, S. 2006. Determining a reasonable concession period for private sector provision of public works and services, Canadian Journal of Civil Engineering 33: 622-631. 